\title{
Assessment of the territorial suitability for the creation of the greenways networks: Methodological application in the Sicilian landscape context
}

\author{
Marzia Quattrone, Giovanna Tomaselli, Lara Riguccio, Patrizia Russo \\ Department of Agriculture, Food and Environment, Building and Land Engineering Section, University of Catania, Italy
}

\begin{abstract}
The proposal to create greenways networks for the enhancement of more or less vast areas is of great importance to territory planning. The paths, which are overlaid on pre-existing linear patterns, promote the development of endogenous resources and facilitate direct learning of the territory's historical, cultural, environmental and landscaping assets. Rural areas can be strongly influenced by setting up a greenways network, as their use not only promotes the exchange of knowledge between users and inhabitants, but also encourages the enjoyment of various areas (agricultural landscapes, scattered cultural heritage, protected environments) that would otherwise be inaccessible due to their distance from the traditional routes. Altogether, this favours the introduction of economic activities based on their typical characteristics. This work identifies the appropriate road infrastructure, available in the former Province of Syracuse (East Sicily), for building greenways networks that will best contribute to the valorisation of their surrounding territory. This work assigns great importance to landscape features as factors of tourist and cultural attraction. We have used the multi-criteria analysis associated with geographic information system (GIS). We have weighed and mapped numerous indicators to define the territory's infrastructural, landscape, cultural, and tourist resources, meaning those able to increase the use of the territory and/or that determine attractiveness for the population. The GIS analysis allowed us to develop numerous intermediate maps, whose information helped us to draw up the final map illustrating the suitability of the existing
\end{abstract}

Correspondence: Giovanna Tomaselli, Department of Agriculture, Food and Environment, Building and Land Engineering Section, University of Catania, Italy.

E-mail: gitomas@unict.it

Key words: Historical routes; abandoned railways; rural landscape; geographic information system; analytic hierarchy process.

Acknowledgements: the authors thank Luciano Matarazzo and Sofia Pesce for contributing to the drafting of the text giving valuable suggestions.

Received for publication: 28 March 2017.

Accepted for publication: 21 July 2017.

(C) Copyright M. Quattrone et al., 2017

Licensee PAGEPress, Italy

Journal of Agricultural Engineering 2017; XLVIII:696

doi:10.4081/jae.2017.696

This article is distributed under the terms of the Creative Commons Attribution Noncommercial License (by-nc 4.0) which permits any noncommercial use, distribution, and reproduction in any medium, provided the original author(s) and source are credited. infrastructures that could be useful while planning of a greenway network. Such infrastructures could be the subject of specific plans or detailed projects aimed at enhancing the pre-existing resources of a rural territory. This study, although referring to a defined territory, is methodologically valid in a general sense and can be used in various contexts.

\section{Introduction}

The term greenway was introduced in 1959 in the United States by William $\mathrm{H}$. Whyte. It is well known that many designers and scientists (Little, 1990; Fabos and Ryan, 2004) consider Frederick Law Olmsted the founder of the greenways movement.

From the very beginning greenways planning captured the interest of the public in the United States and Canada, and received political and academic support, showing that these networks are multifunctional, ecological, and capable of furthering social and economic objectives (Miller et al., 1998; Bateman, 2006). According to Fabos and Ryan (2004) the greenway concept encompasses at least three meanings: primarily, they are ecological corridors, secondly they have recreational functions and, finally, they contribute to the conservation/requalification of an area's historical and cultural heritage.

Ahern (1995) proposed the following definition: Greenways are networks of land containing linear elements that are planned, designed, and managed for multiple purposes including ecological, recreational, cultural, aesthetic, or other purposes compatible with the concept of sustainable land use; Ahern goes on to identify the key concepts within this definition: linear configuration, connection, multi-functionality and, environmental sustainability.

The explosion of the greenways concept in Europe, however, is a recent development, and the involvement of European States has been due to the organisation of seminars and conferences on the greenways and on related planning issues.

In Italy, the Italian Greenways Association (AIG) promotes and divulges the concept of greenways. Homogeneously to the previous definitions, the AIG identifies the greenways as system of routes, good from the environmental point of view and dedicated to a non motorised traffic, connecting people with landscape resources (natural, historical, cultural, etc.) and the 'centres of life' (e.g. public offices, sport and recreational facilities, etc.), both in the urban areas and in the countryside. It further characterises the greenways as a system of linear interconnected territories that are protected, managed and developed in order to obtain the recreational, ecological and cultural-historical benefits.

Transferring the greenway concept to Italy therefore requires an interpretative effort; it is necessary to adapt the very notion of a greenway to a new social and territorial context.

In Italy, and especially in Sicily, compared to the region's exigencies and its potential for an infrastructural network, very little has been done towards the planning and implementation of real green- 
ways networks. In Sicily there are some isolated greenways, which are difficult to use continuously, while a greenways network is conceived a system of interconnected infrastructures, which could be composed of towpaths, river banks, historical streets (Caliandro et al., 2014), disused railways (Senes, 2004; Toccolini, 2004), country roads, trails, panoramic itineraries and bike paths, creating a nonmotorised independent network, created as part of an integrated development, which promotes environmental sustainability and boosts the quality of life. This network could constitute a location for the development of an ecological corridor, connecting various isolated natural areas (De Montis et al., 2016).

Therefore, the proposal to create greenways networks or green paths for the enhancement of more or less large areas is of great importance to land use planning. The paths, which would be overlaid on pre-existing linear patterns (historical roads, dismissed railways, river towpaths, trails, roads of secondary importance), would allow for the development of local resources and support direct knowledge of the area's historical, cultural environmental and landscape heritage. Rural areas can be strongly influenced by the construction of greenways networks as their use not only promotes the exchange of knowledge between network users and inhabitants, but also facilitates the use of areas (agricultural landscapes, cultural heritage, protected sites) otherwise inaccessible due to their distance from the traditional roads. Altogether, this favours the introduction of economic activities (agritourism, refreshment, accommodation facilities, rural tourism, selling typical agricultural and home made products). In Sicily, the main existing greenways are made on short stretches of disused railways, independent of each other and created thanks to the Non-motorised mobility plan in Sicily, adopted on 6 June 2005. The latter, designed as an integral part of the regional transport Plan, were developed with the aim of achieving a regional network of alternative transportation mobility, with a low or no environmental impact ('slow' mobility), with the priority use of the disused railway lines and of other minor or side roads (Regione Sicilia, 2005).

The Plan was designed to further the reuse of almost all the disused railway lines, but also to encourage the use of other routes situated on ancient royal country roads or on standard roads, in order to interconnect individual circuits and to create routes to and across locations of particular value.

The plan identifies two types of paths: the ring paths, the linear paths. The first are short cycle hiking courses, often with a welldefined environmental, landscaping or historical theme, which depart from and feed back into a town or road intersection. The linear paths are characterised by different starting and arrival points, possibly in a row, in order to allow them to be traversed in several phases throughout the regional territory. The plan is important for the public authorities' willingness to create a totally new infrastructure in the region and to consider this infrastructure as part of a network rather than as an isolated one. While the Plan highlights the region's great potential for the creation of a greenways network, it is accompanied only by a description of the functional features of the routes, and lacks an assessment of the territorial and landscape features that justify the recovery, reconversion and infrastructural adjustment on which the greenways network relies (Regione Sicilia, 2005). The guidelines Sicilian regional landscape plan (PTPR), provides even less detail, and indiscriminately identifies $6432 \mathrm{~km}$ of country routes, $838 \mathrm{~km}$ of disused railways, and a dense network of paths (about $4078 \mathrm{~km})$ and stretches of panoramic roads $(2675 \mathrm{~km})$ that could be used for non-motorised traffic. It is clear that not all the kilometres indicated by the above mentioned guidelines are suitable for greenways. The selection of pathways to establish a greenway network, should take place following a meticulous territorial and landscaping analysis, which allows us to identify the attractions that can stimulate the use of the greenways network. Various authors argue that greenways are important elements for the enjoyment and enhancement of the rural areas and that their use depends on the presence of attractions disseminated along the route, of the landscape-environmental type (reserves, natural areas, rivers, lakes, etc.), landscaping-agrofood (agricultural landscapes, cultural landscapes, selling typical products, catering based on the use of the local products, agritourism, etc.) (Taylor, 2015; Ottomano Palisano et al., 2016). It seems appropriate, based on the regional potential and planning guidelines, to acquire the analysis and evaluation tools, that will allow for the proper planning of the most suitable greenways network to stimulate the use of the rural areas and the valorisation of the resources (landscaping, cultural, agro-food) (Riguccio et al., 2015a). Therefore, the objective of this study is to develop a useful method to identify infrastructure systems capable of supporting a greenways network that can contribute to the promotion of areas of particular value. For this purpose, we will adopt the slow regional mobility plan's consideration of the greenways network as the ensemble of road structures, which favour slow travel within the area. This would include paths dedicated exclusively to non-motorised travel, roads that can accommodate both slow and motorised travel which connect the nonmotorised paths, and roads reserved for motor vehicles that equipped with road signs and other useful services to reach the real greenways.

In the Materials and methods section, after a brief description of the reference framework, we outline the methodological steps based on a multi-criteria analysis (MCA), associated with the spatial analysis in a geographic information system (GIS) environment.

In the Results section we show the results of the MCA, for the preparation of the suitability maps, which highlight areas of major interest for the construction of a network.

In the Discussion and conclusions section we summarise the main findings and illustrate the scope for development of this research. The methodology, with appropriate adjustments, suggested by the specific contexts, can be applied to the Italian regions and more generally in territories where the same objective is pursued.

\section{Materials and methods}

\section{Area of research}

The territory considered for the development of this study, coincides with the landscape areas 14 and 17 of PTPR, located in what was previously the Province of Syracuse (and is currently a Consortium of Municipalities). This area is characterised by a surface of $2124 \mathrm{~km}^{2}$ and it is delineated to the North by the Plain of Catania, to the East and South by the Ionian Sea, to the West by the Iblei mountains, which occupy a considerable part of Consortium (Figure 1).

The area boasts numerous archaeological areas (Eloro, Akrai, Tellaro, Megara Hyblea, Thapsos, Pantalica): in the landscape area 17 alone, we have 600 sites recorded by PTPR; for reference, no other landscaped area, among the 17 identified in the PTPR, exceeds 300 sites. The PTPR has recorded, in the same landscape area, 800 isolated assets of high cultural value. Both the landscape areas have about $1625 \mathrm{~km}$ of linear infrastructure that, in accordance with the PTPR, are well suited, to constitute part of a greenway $(1210 \mathrm{~km}$ of royal country roads (trazzere), $167 \mathrm{~km}$ of disused railways, $248 \mathrm{~km}$ of trails). The rural landscape is predominantly agricultural, but crossed by streams recessed in canyons, which shape important landscapes in the Natura 2000 network (rivers Anapo and Tellaro).

The coast preserves important landscapes and natural sites, like 
Vendicari reserve, the Priolo peninsula, the Plemmirio, Capo Passero, etc. despite the petrochemical area in Augusta. The Iblei Mountains, formed by volcanic and calcareous rocks, have furnished the construction materials for the most of the local buildings. The mountains form plateaus that slope down to the sea with large cliffs. The edges of the plateaus, located from 100 to $200 \mathrm{~m}$ above sea level, clearly delimit very different agricultural landscapes: dry crops or orchards with olive and carob trees in the plateaus, and intensive crops (vineyards, greenhouses) on the coast. Of great value and peculiarity is the agricultural landscape characterised by fields enclosed by an extended network of low dry stone walls, protecting arable land and orchards containing olive trees, almond trees in Noto district (Netino) and carob trees, with the latter two quite often found together.

The masserie system (rural buildings built between 1600 and early 1900) is an invaluable architectural heritage, forming a display of ancient rural edifices serving typical agricultural practices such as cereal production and livestock keeping.

\section{Materials}

The territory has been analysed using the thematic shap files of the local landscape plan, developed in accordance with the Code of Cultural Heritage and Landscape (Legislative Decree no. 42 of 22 January 2004) for the landscape areas 14 and 17 of PTPR, provided by the Superintendence of Cultural and Environmental Heritage of Syracuse. We have used the thematic layers data containing the roads, rail, port and airport infrastructures, land use, the landscaping areas such as reserves, parks and Natura 2000 sites, the archaeological sites and places, the rural architecture, the historical centres, rivers and lakes. The subjects have been referred to the base map in raster format in scale 1:100,000. These files have been updated and completed by performing direct surveys and using the data acquired in the Sicily region website and in the regional geographic information system. In addition, in order to acquire the general information on the regional development guidelines and on the socio-economic, environmental and cultural potentialities of the territory, we have consulted the following documents: guidelines of PTPR; rural development plan, Sicily region 2007-2013; regional operational programme Sicily 2000-2006; list of the agricultural products designation of protect origin and protected geographical indication provided by the Ministry of Agriculture and Forestry, 2014; the Sicilian Network Ecological Guidelines 2005; Line of action 3.3.2.4 Implementation of a regional strategic plan for the sweet and/or

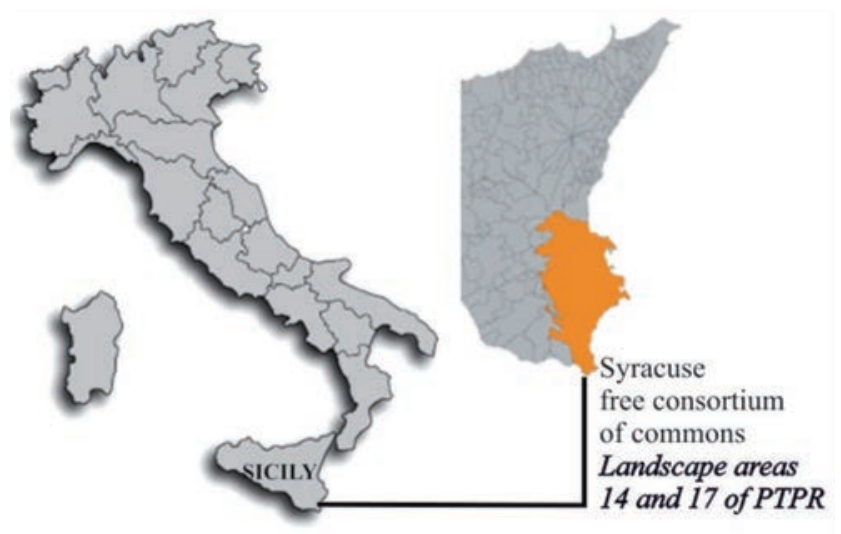

Figure 1. Location of the study area. PTPR, Sicilian Regional Landscape Plan. non-motorised mobility, Sicily region 2009; data from the National Institute of Statistics (ISTAT), and in particular the 2011 agricultural census. We have considered the latest Google Earth ${ }^{\circledR}$ satellite images (June 2014), and its pertinent database concerning especially the location of tourist and commercial services. The cartographic data has been processed with ArcMap 9.2 software and ArcGIS 9 (Esri, Redlands, CA, USA), while the numerical calculations have been developed with EXCEL 2010. We have used 100 questionnaires to obtain the preferences of a population sample on landscape characteristics. The questionnaire model is shown in Figure 2.

\begin{tabular}{|c|c|c|c|c|}
\hline \multicolumn{5}{|c|}{ QUESTIONNAIRE } \\
\hline \multicolumn{5}{|c|}{$\begin{array}{l}\text { Express the importance degree that these resources could take for the } \\
\text { landscape enhancement of the territory, by developing a greenways } \\
\text { network (dedicated paths to slow mobility, pedestrian and cycle tracks): }\end{array}$} \\
\hline \multicolumn{5}{|c|}{ Interviewee personal data } \\
\hline \multicolumn{5}{|c|}{ Age group: $\quad<30$ vears; $\quad>30<50$ vears; } \\
\hline \multicolumn{5}{|c|}{$\begin{array}{lll}\text { Education level: } & \begin{array}{c}\text { University degree; } \\
\text { Junior high school }\end{array} & \text { High school degree; } \\
\end{array}$} \\
\hline \multicolumn{5}{|c|}{ Town: :.......................................................... } \\
\hline \multicolumn{5}{|c|}{$\begin{array}{cc} & \text { Alternatives } \\
\end{array}$} \\
\hline \multicolumn{5}{|c|}{$\begin{array}{l}\text { A1 - To establish a greenways network that can promote the } \\
\text { development agro-Rural } \\
\text { A2 - To develop a greenways network can encourage the Tourist - } \\
\text { Cultural use } \\
\text { A3 - To realize a network of greenways that can promote the use of } \\
\text { Environmental values }\end{array}$} \\
\hline \multirow{2}{*}{ Cod. } & \multirow{2}{*}{$\begin{array}{l}\text { Description } \\
\text { INFRASTRUCTURE } \\
\text { RESOURCES }\end{array}$} & \multicolumn{3}{|c|}{ Value } \\
\hline & & High & Medium & Low \\
\hline $\mathrm{I}_{1,1}$ & Highways & & & \\
\hline$I_{1,2}$ & State roads & & & \\
\hline$I_{1,3}$ & $\begin{array}{l}\text { Regional and } \\
\text { provincial roads }\end{array}$ & & & \\
\hline $\mathrm{I}_{1,4}$ & Active railway tracks & & & \\
\hline 1,5 & Desused railway tracks & & & \\
\hline$I_{1,6}$ & Ports and Airports & & & \\
\hline$I_{1,7}$ & $\begin{array}{l}\text { Paths and royal } \\
\text { country roads }\end{array}$ & & & \\
\hline $\mathrm{I}_{1.8}$ & Parking/rest areas & & & \\
\hline $\mathbf{I}_{\mathbf{2}}$ & $\begin{array}{l}\text { NATURAL AND } \\
\text { ECOLOGICAL RESOURCES }\end{array}$ & High & Mean & Low \\
\hline$\left.\right|_{2,1}$ & $\begin{array}{l}\text { Land use and } \\
\text { agricultural landscape }\end{array}$ & & & \\
\hline 12,2 & $\begin{array}{l}\text { Natural reserve and } \\
\text { parks, SIC/ZPS zones }\end{array}$ & & & \\
\hline $\mathrm{I}_{2,3}$ & Waterways & & & \\
\hline la & $\begin{array}{l}\text { HISTORICAL AND } \\
\text { CULTURAL RESOURCES }\end{array}$ & High & Mean & Low \\
\hline 13,1 & Archeological sites & & & \\
\hline 13,2 & Historical centers & & & \\
\hline$I_{3,3}$ & $\begin{array}{l}\text { Museums and eco- } \\
\text { museums }\end{array}$ & & & \\
\hline$l_{3,4}$ & $\begin{array}{l}\text { Rural Architecture/ } \\
\text { architectural } \\
\text { landscape elements }\end{array}$ & & & \\
\hline$I_{4}$ & $\begin{array}{l}\text { COMMERCIAL } \\
\text { RESOURCES } \\
\text { AND SERVICES }\end{array}$ & High & Mean & Low \\
\hline 14,1 & $\begin{array}{l}\text { Agricultural holdings } \\
\text { /educational } \\
\text { farms/agritourisms/ca } \\
\text { mpings }\end{array}$ & & & \\
\hline l4,2 & $\begin{array}{l}\text { Hotel facilities / B \& B / } \\
\text { hostels }\end{array}$ & & & \\
\hline |4,3 & Rural and folk festivals & & & \\
\hline
\end{tabular}

Figure 2. Standard questionnaire provided to the sample of residents. 


\section{Methods}

\section{Multi-criteria analysis}

Once a single objective had been identified (goal) - to identify the infrastructural system able to support the greenways network that would best contribute to the enhancement of the Syracuse territory - we have envisioned a finite number of alternatives able to justify the realisation of a greenways network. The decision-making process was then centred on the alternatives, as defined by Keeney (1992), to select the best alternative (Mauchline, 2012).

Among the various MCA, the analytic hierarchy process (AHP) is widely applied in the territorial planning field. The AHP addresses the evaluation process through several distinct phases by taking, as a general methodical rule, the division of the overall problem of choice into a series of smaller and easier solving problems. This method, at the end of the process, assigns each decisionmaking alternative a score, which represents the overall performance, obtained thanks to the performances the alternatives present on the individual evaluation criteria. This method, though mathematically complex, tends to simplify the interaction between analyst and decision maker, being able to deal with problems where a good part of the data is of soft type (qualitative type) (Saaty, 1990).

According to William Ho (2008) its wide applicability is due to its great flexibility, simplicity and user friendliness. Moreover, an advantage considered to be one of the most important to AHP is given by the ability to verify the consistency of judgments by computing the consistency ratio, which must not exceed $10 \%$.

The suggested alternatives are: $\mathrm{A}_{1}$ - to establish a greenways network that can promote agro-rural development (Russo et al., 2014; Riguccio et al., 2015a); A 2 - to develop a greenways network that can encourage tourism and cultural enjoyment in the area (De Montis et al., 2015; Diti et al., 2015; Taylor, 2015); A3 - to realise a network of greenways that can promote ecological activities (Fichera et al., 2015; Riguccio et al., 2016). These proposals arise from the study of the scientific literature, from specialists' opinions and from information contained in consulted cartographic, digital and documentary sources (Marcheggiani et al., 2011).

The $A_{1}$ alternative is based on the creation of greenways with rural purposes, meaning a type of infrastructure that can enhance the rural landscape and promote the development of activities related to the recovery and restoration of the rural heritage.

The $A_{2}$ alternative would establish greenways with touristic and cultural purposes, for the enjoyment of the cultural, archaeological, historical, natural, landscape resources. This use promotes the integration of the enhancement process with the provision of services and with other related productive sectors.

The $A_{3}$ alternative is based on the development of greenways with environmental objectives, such as maintaining biodiversity and facilitating the use of valuable landscape areas.

Given the objectives, the indicators $\left(\mathrm{I}_{\mathrm{mn}}\right)$ or criteria selected are those reported and accompanied by their meanings in Table 1.

The indicators are part of the following territorial systems: infrastructural $\left(\mathrm{I}_{1}\right)$, agri-natural $\left(\mathrm{I}_{2}\right)$, historical-cultural $\left(\mathrm{I}_{3}\right)$, commercial $\left(I_{4}\right)$, explained by the indicators: $I_{1 n}, I_{2 n}, I_{3 n}, I_{4 n}$. The term system is hereinafter used to indicate the territory components (in this case the indicators) that interact with one another in order to fulfil a specific function (infrastructural, natural, historical-cultural, commercial) (Mazzino and Ghersi, 2002).

The pairwise comparison between Im systems and the Imn indicators, executed with respect to each alternative $A_{1}, A_{2}, A_{3}$, has provided the relevant weightings. In this case the weightings were assigned according to the Saaty scale (1990) (1-Equal importance, 3-Moderate importance of one over another; 5-Essential or strong importance; 7-Very strong importance; 9-Extreme importance). The matrices have been developed by the research team members who are experts on territory planning with many years of research experience in the specific field. We have verified the consistency of judgments by computing the consistency ratio.

\section{Questionnaires}

The evaluation of the systems and indicators also takes into account the results of questionnaires distributed to a sample of 100 inhabitants living in the Syracuse area, of heterogeneous age and level of education.

The questionnaire was distributed at meeting places (squares, cafes), shopping centres and at the Faculty of Architecture of the University of Catania at a prime time of attendance. We asked participants to assign a qualitative value (high, medium, low) to the systems of indicators under consideration, and their ability to enhance the landscape of the territory, by developing a greenways network with respect to the three proposed alternatives $\left(A_{1}, A_{2}\right.$, $\left.\mathrm{A}_{3}\right)$.

The results of the interviews were considered and the qualitative judgements were recorded on the two matrices using the symbols,,,++++-- and -- , where the symbol ++ represents the maximum satisfaction value of the $\mathrm{I}_{\mathrm{m}}$ system (in the first matrix) or indicator $\mathrm{I}_{\mathrm{mn}}$ (in the second matrix) compared to the alternative $A_{n}$ and, vice versa, the symbol - - represents the non-satisfaction of the $I_{n}$ system or of the indicator $I_{m n}$ compared to the alternative $A_{n}$.

Therefore, in the first matrix, we assign the qualitative weight that each system $\left(\mathrm{I}_{1}, \mathrm{I}_{2}, \mathrm{I}_{3}, \mathrm{I}_{4}\right)$ assumes with respect to each hypothesised alternative $\left(\mathrm{A}_{1}, \mathrm{~A}_{2}, \mathrm{~A}_{3}\right)$.

In the second matrix we have given the qualitative weight that each indicator $\left(I_{1 n}, I_{2 n}, I_{3 n}, I_{4 n}\right)$ assumes with respect to each hypothesised alternative $\left(\mathrm{A}_{1}, \mathrm{~A}_{2}, \mathrm{~A}_{3}\right)$.

The five levels of satisfaction arise from the number of high preferences given by the respondents. Although we have not considered the preferences granted by the respondents with respect to the opinions medium and low, we believe that the inclusion of these options in the questionnaire sheet, compels the respondents to a more careful consideration on the preferences to be provided, allowing them to smooth their own opinion. In the Table 2 we find the thresholds of the number of preferences corresponding to the high value, associated with each symbol.

The $I_{m n}$ thresholds stem from the high number of preferences given by the respondents to each $\mathrm{I}_{\mathrm{mn}}$ indicator, while the thresholds related to $I_{m}$ stem from the sum of high preferences given by the respondents to the indicators of the belonging system.

Subsequently, the data contained in the matrices, has been normalised by assigning to the linguistic opinion ++ a value of 1 and to the opinion language - - a value of 0 . Assigning the value 1 to an indicator means that given indicator maintains the weighting obtained from pairwise comparison in the AHP, because more than $80 \%$ of respondents assign a high value to the pertinent indicator. Assigning a 0 to an indicator, the indicator is discounted, as it collects a number of preferences lower than the minimum thresholds, as less than $20 \%$ of respondents assigned it a high value.

Therefore, to obtain the order of the alternatives, the weights obtained by the pairwise comparison have been associated to those recorded in the first evaluation matrices, multiplying the values.

The double application (matrices of evaluation and pairwise comparison of $\mathrm{I}_{\mathrm{m}}$ systems and matrices of evaluation and pairwise comparison of $I_{m n}$ indicators, for the alternatives $A_{1}, A_{2}, A_{3}$ ), 
Table 1. Description of the indicators separated for systems.

Objective System Indicator Description

Identify the infrastructural system

able to establish

the greenways network

\begin{tabular}{|c|c|c|}
\hline \multirow[t]{8}{*}{ Il - Infrastructural } & I,1 Highway & $\begin{array}{l}\text { Suburban or urban road infrastructure reserved for fast traffic, } \\
\text { multi-lane }\end{array}$ \\
\hline & $\mathrm{I}_{1,2}$ National road & Road of national importance managed by the State \\
\hline & $\begin{array}{l}\mathrm{I}_{1,3} \text { Regional and } \\
\text { provincial road }\end{array}$ & $\begin{array}{l}\text { State-owned roads connecting the provincial capitals in the } \\
\text { same region with each other or with the regional capital } \\
\text { or connecting the provincial capitals or municipalities } \\
\text { with the state network }\end{array}$ \\
\hline & $\mathrm{I}_{1,4}$ Active railway lines & Active railway lines in the territory \\
\hline & $\mathrm{I}_{1,5}$ Disused railway lines & Old disused railway lines \\
\hline & $\mathrm{I}_{1,6}$ Ports/Airports & Structures for unloading goods/embarkation activities \\
\hline & $\begin{array}{l}\mathrm{I}_{1,7} \text { Paths/royal country } \\
\text { roads }\end{array}$ & Agricultural farm tracks and country roads \\
\hline & $\mathrm{I}_{1,8}$ Parking/rest areas & Devoted cars/campers parking and picnic areas \\
\hline
\end{tabular}

$\mathrm{I}_{2}$ - Agri-natural
I2,1 Land use
Agricultural area devoted to the cultivation (citrus, vineyards, arable land, tree crops)

I,2 Areas of significant landscape and environmental interest

National and regional parks, nature reserves, marine parks and other protected natural areas; Special Areas for Conservation (SAC) and Areas for Special Protection (ASP)identified by Decree of the Office for Land and Environment of 21/02/2005 published in the Official Gazette of Sicily Region No. 42 of 7/10/2005

I,3 Waterways Natural elements like rivers and brooks

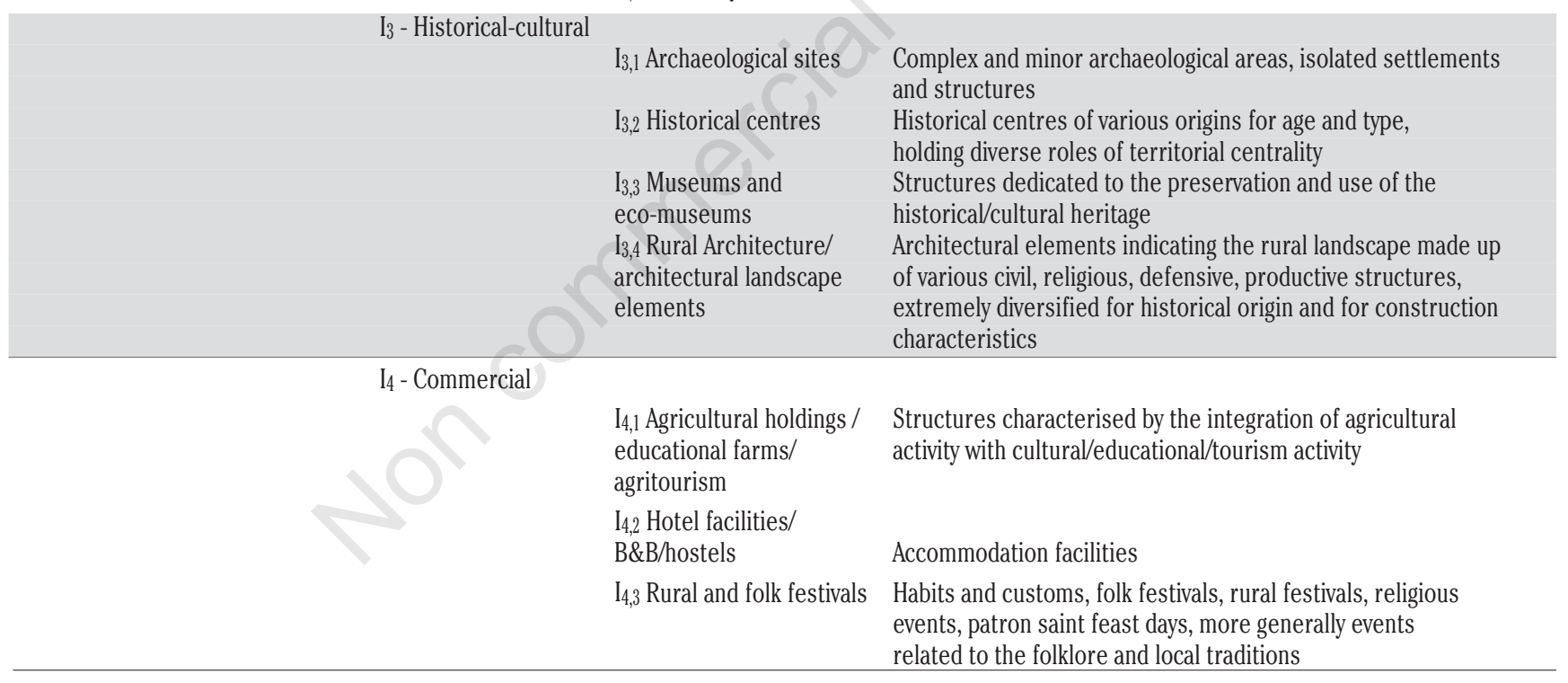

Table 2. Thresholds of the number of preferences corresponding to the bigh value, associated with each symbol.

\begin{tabular}{|c|c|c|c|c|c|}
\hline & for $I_{n m}$ & for $I_{1}$ & $\begin{array}{l}\text { Preferences } \\
\text { for } I_{2}\end{array}$ & for $I_{3}$ & for $\mathrm{I}_{4}$ \\
\hline-- & From 0 to 19 & From 0 to 152 & From 0 to 57 & From 0 to 76 & From 0 to 57 \\
\hline- & From 20 to 39 & From 153 to 312 & From 58 to 117 & From 77 to 156 & From 58 to 117 \\
\hline+- & From 40 to 59 & From 313 to 472 & From 118 to 177 & From 157 to 236 & From 118 to 177 \\
\hline+ & From 60 to 79 & From 473 to 632 & From 178 to 237 & From 237 to 316 & From 178 to 237 \\
\hline++ & From 80 to 100 & From 633 to 800 & From 238 to 300 & From 317 to 400 & From 238 to 300 \\
\hline
\end{tabular}

$I_{n m}$, indicator; $I_{1}$, infrastructural system; $I_{2}$, agri-natural system; $I_{3}$, historical-cultural system; $I_{4}$, commercial system. 
allows obtaining more reliable results compared to a single evaluation process.

\section{Geographic information system mapping}

In order to achieve the proposed objective we have operated using the GIS potentialities with the MCA (Riguccio et al., 2015b).

We differentiate two phases. The first phase where we have constructed the data structure of the indicators in a GIS environment. We have started by creating the GIS project, inserting the basic mapping in raster format and setting up the Monte Mario Italy 2 (GCS Monte Mario) reference system. Subsequently, we have added the shape files which describe the following indicators: $\mathrm{I}_{1.1}, \mathrm{I}_{1.2}, \mathrm{I}_{1.3}, \mathrm{I}_{1.4}, \mathrm{I}_{1.5}, \mathrm{I}_{1.6}, \mathrm{I}_{1.7}, \mathrm{I}_{1.8}$ (infrastructures); $\mathrm{I}_{2.1}$ (land use); $\mathrm{I}_{2.2}$ (areas of significant landscape and environmental interest); $\mathrm{I}_{2.3}$ (waterways); I $\mathrm{I}_{3.1}, \mathrm{I}_{3.2}, \mathrm{I}_{3.3}, \mathrm{I}_{3.4}$ (archaeological sites, historical centres, museums and eco-museums, rural architecture/architectural landscape elements). We have created new shape files for $\mathrm{I}_{4,1}$ (agricultural holdings/educational), I4,2 (hotel facilities/B\&B/hostels); $\mathrm{I}_{4.3}$ (rural and folk festivals). From this stage the basic thematic maps were obtained.

The second phase was devoted to GIS modelling of the alternative, among the three, that best meets the main objective of the multi criteria hierarchy tree. Therefore, at this stage, we took into account only the weights of the winning alternative indicators.

To each spatial entity of the database (georeferenced indicator) has been associated (by the attribute grid) with the weight obtained by MCA. We asked the system to represent in raster format the weight value of each indicator. For the rasterization, we have chosen cells of sizes $500 \times 500 \mathrm{~m}$, as the punctual indicators of structural and cultural systems have been represented with their respective minimum size buffers, corresponding to the circle included in this cell. We have worked with the raster calculator function, to obtain, first, the weights amount of each system, by adding the weights of the afferent indicators, and consequently the amount of the winning alternative, by adding the weights of all the indicators.

\section{Results}

\section{Multi-criteria analysis}

We have constructed the pairwise comparison matrix (Pairwise comparison matrix) between $\mathrm{I}_{\mathrm{m}}$ systems and among $\mathrm{I}_{\mathrm{mn}}$ indicators, for the three scenarios $A_{1}, A_{2}, A_{3}$. The values of the priority vector and the consistency ratio are reported in Table 3.

The matrices of the first hierarchical level (pairs comparison of the systems) referring to the three scenarios, produced the following results: i) in hypothesis $A_{1}$ (rural purposes), the $I_{2}$ system is assigned more weight. In this case the natural resources are on average more important than the historical-cultural resources and

Table 3. Weights and consistency ratio obtained by the pairwise comparison.

\begin{tabular}{|c|c|c|c|c|c|c|c|}
\hline & & & & & & & \\
\hline In & $\mathrm{I}_{\mathrm{nm}}$ & $\mathbf{P}$ & CR & $\mathrm{P}$ & CR & P & CR \\
\hline $\mathrm{I}_{1}$ & & 0.20 & & 0.21 & & 0.13 & \\
\hline $\mathrm{I}_{2}$ & & 0.32 & & 0.30 & & 0.46 & \\
\hline $\mathrm{I}_{3}$ & & 0.19 & & 0.25 & & 0.17 & \\
\hline$I_{4}$ & & 0.29 & 0.06 & 0.24 & 0.02 & 0.24 & 0,08 \\
\hline $\mathrm{I}_{1}$ & $\begin{array}{l}\mathrm{I}_{1.1} \\
\mathrm{I}_{1.2} \\
\mathrm{I}_{1.3} \\
\mathrm{I}_{1.4} \\
\mathrm{I}_{1.5} \\
\mathrm{I}_{1.6} \\
\mathrm{I}_{1.7} \\
\mathrm{I}_{1.8}\end{array}$ & $\begin{array}{l}0.14 \\
0.09 \\
0.13 \\
0.13 \\
0.17 \\
0.12 \\
0.16 \\
0.05\end{array}$ & & $\begin{array}{l}0.17 \\
0.08 \\
0.08 \\
0.16 \\
0.15 \\
0.17 \\
0.14 \\
0.05\end{array}$ & & $\begin{array}{l}0.14 \\
0.07 \\
0.07 \\
0.15 \\
0.20 \\
0.13 \\
0.18 \\
0.05\end{array}$ & \\
\hline $\mathrm{I}_{2}$ & $\begin{array}{l}\mathrm{I}_{2.1} \\
\mathrm{I}_{2.2} \\
\mathrm{I}_{2.3}\end{array}$ & $\begin{array}{l}0.66 \\
0.16 \\
0.19\end{array}$ & 0.05 & $\begin{array}{l}0.24 \\
0.55 \\
0.21\end{array}$ & 0.04 & $\begin{array}{l}0.26 \\
0.41 \\
0.33\end{array}$ & 0.03 \\
\hline $\mathrm{I}_{3}$ & $\begin{array}{l}\mathrm{I}_{3.1} \\
\mathrm{I}_{3.2} \\
\mathrm{I}_{3.3} \\
\mathrm{I}_{3.4}\end{array}$ & $\begin{array}{l}0.14 \\
0.23 \\
0.23 \\
0.39\end{array}$ & 0.03 & $\begin{array}{l}0.31 \\
0.31 \\
0.24 \\
0.14\end{array}$ & 0.02 & $\begin{array}{l}0.21 \\
0.21 \\
0.29 \\
0.29\end{array}$ & 0.04 \\
\hline $\mathrm{I}_{4}$ & $\begin{array}{l}\text { I } 4.1 \\
I_{4.2} \\
I_{4.3}\end{array}$ & $\begin{array}{l}0.50 \\
0.14 \\
0.37\end{array}$ & 0.08 & $\begin{array}{l}0.26 \\
0.41 \\
0.33\end{array}$ & 0.04 & $\begin{array}{l}0.43 \\
0.35 \\
0.22\end{array}$ & 0.04 \\
\hline
\end{tabular}

$\mathrm{I}_{\mathrm{n}}$, systems; $\mathrm{I}_{\mathrm{n}} \mathrm{m}$, indicators; P, priority vector; $\mathrm{CR}$, consistency ratio; $\mathrm{Al}$, to establish a greenways network that can promote the development agro-rural; A2, to develop a greenways network can encourage the tourist, cultural use; $\mathrm{A}_{3}$, to realise a network of greenways that can promote the use of environmental values; $\mathrm{I}_{1}$, infrastructural system; I2, agri-natural system; I3, historical, cultural system; I4, commercial system; $\mathrm{I}_{1} .1$, highway; $\mathrm{I}_{1.2}$, national road; $\mathrm{I}_{1.3}$, regional and provincial road; $\mathrm{I}_{1.4}$, active railway lines; $\mathrm{I}_{1.5}$, disused railway lines; $\mathrm{I}_{1.6}$, ports/airports; $\mathrm{I}_{1.7}$, paths/royal country roads; I1.8, parking/rest areas; $\mathrm{I}_{2.1}$, land use; $\mathrm{I}_{2.2}$, areas of significant landscape and environmental interest; I2.3, waterways; I3.1, archaeological sites; I3.2, historical centres; I3.3, museums and eco-museums; I3.4, rural architecture/architectural landscape elements; I4.1, agricultural holdings/educational farms/agritourism; I4.2, hotel facilities/B\&B/hostels; I4.3, rural and folk festivals. 
the infrastructures, but equally important to the commercial resources of rural type (agritourism, educational farms, agricultural holding, festivals and popular celebrations); ii) in the $\mathrm{A}_{2}$ scenario (tourist-cultural purposes), in the context of a tourist purpose, the natural, historical-cultural and commercial resources, that offer services to tourists, are of considerable importance, and present valuable opportunities to promote the visit of these places; iii) in the $A_{3}$ scenario (naturalistic purpose), the system $I_{2}$ appears on average more important than the other systems, because the presence of natural reserves, parks and protected areas, becomes the fundamental element for this type of intended use.

The matrices of the second hierarchical level (pairs comparison among indicators) referring to the three scenarios produced the following results: i) in alternative $A_{1}$ the indicators concerning footpaths/royal country road $\left(\mathrm{I}_{1,7}\right)$, disused railway lines $\left(\mathrm{I}_{1,5}\right)$, land use and agricultural landscape $\left(I_{2,1}\right)$, waterways $\left(I_{2,3}\right)$, rural architecture and architectural elements of the landscape $\left(\mathrm{I}_{3,4}\right)$, agricultural holdings/educational farms/agritourism $\left(\mathrm{I}_{4,1}\right)$, festivals and popular celebrations $\left(\mathrm{I}_{4,3}\right)$ were considered extremely important; ii) in the $\mathrm{A}_{2}$ scenario the most of the indicators concerning the infrastructure system $\left(\mathrm{I}_{1,1}, \mathrm{I}_{1,4}, \mathrm{I}_{1,5}, \mathrm{I}_{1,6}, \mathrm{I}_{1,7}\right)$, natural reservesparks/European Special Areas for Conservation (SAC)/Areas for Special Protection (ASP) $\left(\mathrm{I}_{2,2}\right)$, archaeological sites $\left(\mathrm{I}_{3,1}\right)$, villages and historical centres $\left(I_{3,2}\right)$, museums and eco-museums $\left(I_{4,1}\right)$, agricultural holdings/educational farms/agritourism, hotels/B\&B/hostels $\left(\mathrm{I}_{4,2}\right)$, festivals and popular celebrations $\left(\mathrm{I}_{4,3}\right)$, were considered extremely important; iii) in the $\mathrm{A}_{3}$ scenario, the indicators relating to the natural system $\left(I_{2,1}, I_{2,2}, I_{2,3}\right)$, and among the infrastructures the unused railway lines $\left(\mathrm{I}_{1,5}\right)$, get the highest weight. Furthermore, are very important the museums and eco-museums $\left(\mathrm{I}_{3,3}\right)$, rural architecture/architectural landscape elements $\left(\mathrm{I}_{3,4}\right)$, and some commercial facilities that provide nature-related activities ( $\mathrm{I}_{4,1}$ - agricultural holdings/educational farms/agritourism) were considered important.

\section{Questionnaires}

A percentage of $62 \%$ of the respondents had a high school diploma, $26 \%$ graduate, $6 \%$ of secondary school. $62 \%$ of the chosen sample was under 30 years old, $30 \%$ was between 30 and 50 years old, $8 \%$ was aged more than 50 years old. The preferences of this sample are reported in Table 4.
Regarding the scenario $\mathrm{A}_{1}$ (greenway network for rural purposes), all the indicators belonging to the four considered systems $\left(\mathrm{I}_{1}, \mathrm{I}_{2}, \mathrm{I}_{3}, \mathrm{I}_{4}\right)$ have received a number of preferences of high quality in the numeric range $178 \div 632$ (symbol + ). The infrastructural system allows reaching the areas of rural use; furthermore the presence of commercial port facilities promotes the export of the agricultural products (De Montis et al., 2016). The natural system ( $\left.I_{2}\right)$ has a positive view of course, as well as the $\mathrm{I}_{3}$ system that contains the isolated rural assets and the landscape architectural elements; the $\mathrm{I}_{4}$ system is positive as well, because the farms and the educational agricultural holdings, folk festivals, contribute to the production/promotion of the characteristic local products and to the contact with rural activities.

The $A_{2}$ scenario (greenway network for tourism-cultural purposes), has reported that more than $80 \%$ of respondents considered of high importance all indicators (the sum of preferences is between 238 and 800). The infrastructural system is of great importance for the tourism sector because it allows a place to be reached more or less quickly by various transport means (car, bus, train, plane) and because the roads could be considered as a secondary network to support the greenways.

The $A_{3}$ scenario (greenway network for environmental purposes) has collected the lowest number of preferences with high classification rate, while remaining on large numbers. The natural system $\mathrm{I}_{2}$ has been considered extremely important; the $\mathrm{I}_{3}$, which contains the ecological museums, are quite important and the I4, composed of commercial structures as well, that promote activities in contact with nature (agricultural holding/educational farms/agritourism).

Table 5 shows the qualitative and normalised weights pertinent to the systems $\left(\mathrm{I}_{\mathrm{m}}\right)$, indicators $\left(\mathrm{I}_{\mathrm{mn}}\right)$ and referring to the three alternatives $\left(A_{1}, A_{2}, A_{3}\right)$.

The weights obtained by the pairwise comparison, weighed with those obtained from the interviews, indicate the alternative A2, tourist-cultural purposes, as the most suitable to evaluate the potential of the territory in the Syracuse province, by developing an integrated system of greenways (Table 6).

\section{Geographic information system mapping}

The indicators of the infrastructural system $\left(\mathrm{I}_{1}\right)$ show the presence of important infrastructures like the highways $(110.00 \mathrm{~km})$

Table 4. Preferences of the sample of residents interviewed.

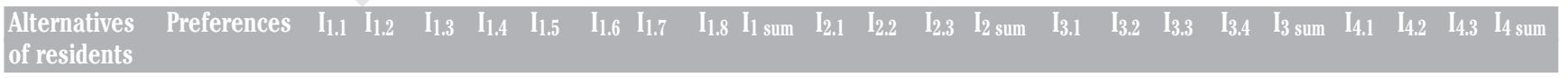

\begin{tabular}{|c|c|c|c|c|c|c|c|c|c|c|c|c|c|c|c|c|c|c|c|c|c|c|c|}
\hline$A l$ & $\begin{array}{l}\text { High } \\
\text { Medium } \\
\text { Low }\end{array}$ & $\begin{array}{c}58 \\
28 \\
14 \\
100\end{array}$ & $\begin{array}{c}57 \\
26 \\
17 \\
100\end{array}$ & $\begin{array}{c}68 \\
26 \\
6 \\
100\end{array}$ & $\begin{array}{c}39 \\
43 \\
18 \\
100\end{array}$ & $\begin{array}{c}100 \\
0 \\
0 \\
100\end{array}$ & $\begin{array}{c}38 \\
47 \\
15 \\
100\end{array}$ & $\begin{array}{c}94 \\
4 \\
2 \\
100\end{array}$ & $\begin{array}{c}38 \\
36 \\
26 \\
100\end{array}$ & $\begin{array}{c}492 \\
210 \\
98 \\
800\end{array}$ & $\begin{array}{c}85 \\
11 \\
4 \\
100\end{array}$ & $\begin{array}{c}58 \\
29 \\
13 \\
100\end{array}$ & $\begin{array}{c}81 \\
12 \\
7 \\
100\end{array}$ & $\begin{array}{c}224 \\
52 \\
24 \\
300\end{array}$ & $\begin{array}{c}39 \\
36 \\
25 \\
100\end{array}$ & $\begin{array}{c}77 \\
16 \\
7 \\
100\end{array}$ & $\begin{array}{c}39 \\
37 \\
24 \\
100\end{array}$ & $\begin{array}{c}89 \\
11 \\
0 \\
100\end{array}$ & $\begin{array}{c}244 \\
100 \\
56 \\
400\end{array}$ & $\begin{array}{c}83 \\
12 \\
5 \\
100\end{array}$ & $\begin{array}{c}39 \\
35 \\
26 \\
100\end{array}$ & $\begin{array}{c}81 \\
13 \\
6 \\
100\end{array}$ & $\begin{array}{c}203 \\
60 \\
37 \\
300\end{array}$ \\
\hline$A 2$ & $\begin{array}{l}\text { High } \\
\text { Medium } \\
\text { Low }\end{array}$ & $\begin{array}{c}86 \\
12 \\
2 \\
100\end{array}$ & $\begin{array}{c}85 \\
9 \\
6 \\
100\end{array}$ & $\begin{array}{c}83 \\
14 \\
3 \\
100\end{array}$ & $\begin{array}{c}82 \\
15 \\
3 \\
100\end{array}$ & $\begin{array}{c}100 \\
0 \\
0 \\
100\end{array}$ & $\begin{array}{c}81 \\
15 \\
4 \\
100\end{array}$ & $\begin{array}{c}96 \\
4 \\
0 \\
100\end{array}$ & $\begin{array}{c}80 \\
13 \\
7 \\
100\end{array}$ & $\begin{array}{c}693 \\
82 \\
25 \\
800\end{array}$ & $\begin{array}{c}59 \\
27 \\
14 \\
100\end{array}$ & $\begin{array}{c}100 \\
0 \\
0 \\
100\end{array}$ & $\begin{array}{c}79 \\
18 \\
3 \\
100\end{array}$ & $\begin{array}{c}238 \\
45 \\
17 \\
300\end{array}$ & $\begin{array}{c}96 \\
4 \\
0 \\
100\end{array}$ & $\begin{array}{c}95 \\
5 \\
0 \\
100\end{array}$ & $\begin{array}{c}91 \\
8 \\
1 \\
100\end{array}$ & $\begin{array}{c}82 \\
11 \\
7 \\
100\end{array}$ & $\begin{array}{c}364 \\
28 \\
8 \\
400\end{array}$ & $\begin{array}{c}90 \\
8 \\
2 \\
100\end{array}$ & $\begin{array}{c}98 \\
2 \\
0 \\
100\end{array}$ & $\begin{array}{c}89 \\
9 \\
2 \\
100\end{array}$ & $\begin{array}{c}277 \\
19 \\
12 \\
300\end{array}$ \\
\hline & $\begin{array}{l}\text { High } \\
\text { Medium } \\
\text { Low }\end{array}$ & $\begin{array}{c}58 \\
34 \\
8 \\
100\end{array}$ & $\begin{array}{c}57 \\
30 \\
13 \\
100 \\
\end{array}$ & $\begin{array}{c}62 \\
29 \\
9 \\
100\end{array}$ & $\begin{array}{c}19 \\
46 \\
35 \\
100\end{array}$ & $\begin{array}{c}88 \\
8 \\
4 \\
100\end{array}$ & $\begin{array}{c}18 \\
48 \\
34 \\
100\end{array}$ & $\begin{array}{c}89 \\
11 \\
0 \\
100\end{array}$ & $\begin{array}{c}19 \\
52 \\
29 \\
100\end{array}$ & $\begin{array}{l}410 \\
258 \\
132 \\
800\end{array}$ & $\begin{array}{c}82 \\
10 \\
8 \\
100\end{array}$ & $\begin{array}{c}85 \\
15 \\
0 \\
100\end{array}$ & $\begin{array}{c}82 \\
16 \\
2 \\
100\end{array}$ & $\begin{array}{c}249 \\
41 \\
10 \\
300\end{array}$ & $\begin{array}{c}58 \\
33 \\
9 \\
100 \\
\end{array}$ & $\begin{array}{c}57 \\
35 \\
8 \\
100\end{array}$ & $\begin{array}{c}85 \\
13 \\
2 \\
100\end{array}$ & $\begin{array}{c}79 \\
18 \\
3 \\
100 \\
\end{array}$ & $\begin{array}{c}279 \\
99 \\
22 \\
400\end{array}$ & $\begin{array}{c}91 \\
6 \\
3 \\
100\end{array}$ & $\begin{array}{c}19 \\
45 \\
36 \\
100\end{array}$ & $\begin{array}{c}78 \\
14 \\
8 \\
100\end{array}$ & $\begin{array}{c}188 \\
65 \\
69 \\
300\end{array}$ \\
\hline
\end{tabular}

$\mathrm{A}_{1}$, to establish a greenways network that can promote the development agro-rural; $\mathrm{A}_{2}$, to develop a greenways network can encourage the tourist, cultural use; $\mathrm{A}_{3}$, to realise a network of greenways that can promote the use of environmental values; $I_{1}$, infrastructural system; $I_{2}$, agri-natural system; $I_{3}$, historical, cultural system; $I_{4}$, commercial system; $I_{1.1}$, highway; $I_{1.2}$, national road; $I_{1.3}$, regional and provincial road; $I_{1.4}$, active railway lines; I..5, disused railway lines; I.6, ports/airports; 1.7, paths/royal country roads; I.8, parking/rest areas; I2.1, land use; I.2. areas of significant landscape and environmental interest; I 2.3 , waterways; I3.1, archaeological

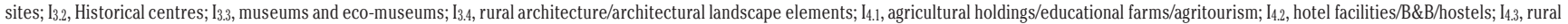
and folk festivals. In italics preferences considered. 
Table 5. Qualitative and normalised weights pertinent to the systems (In) and indicators (Imn), referring to the three alternatives (A1, A2, A3).

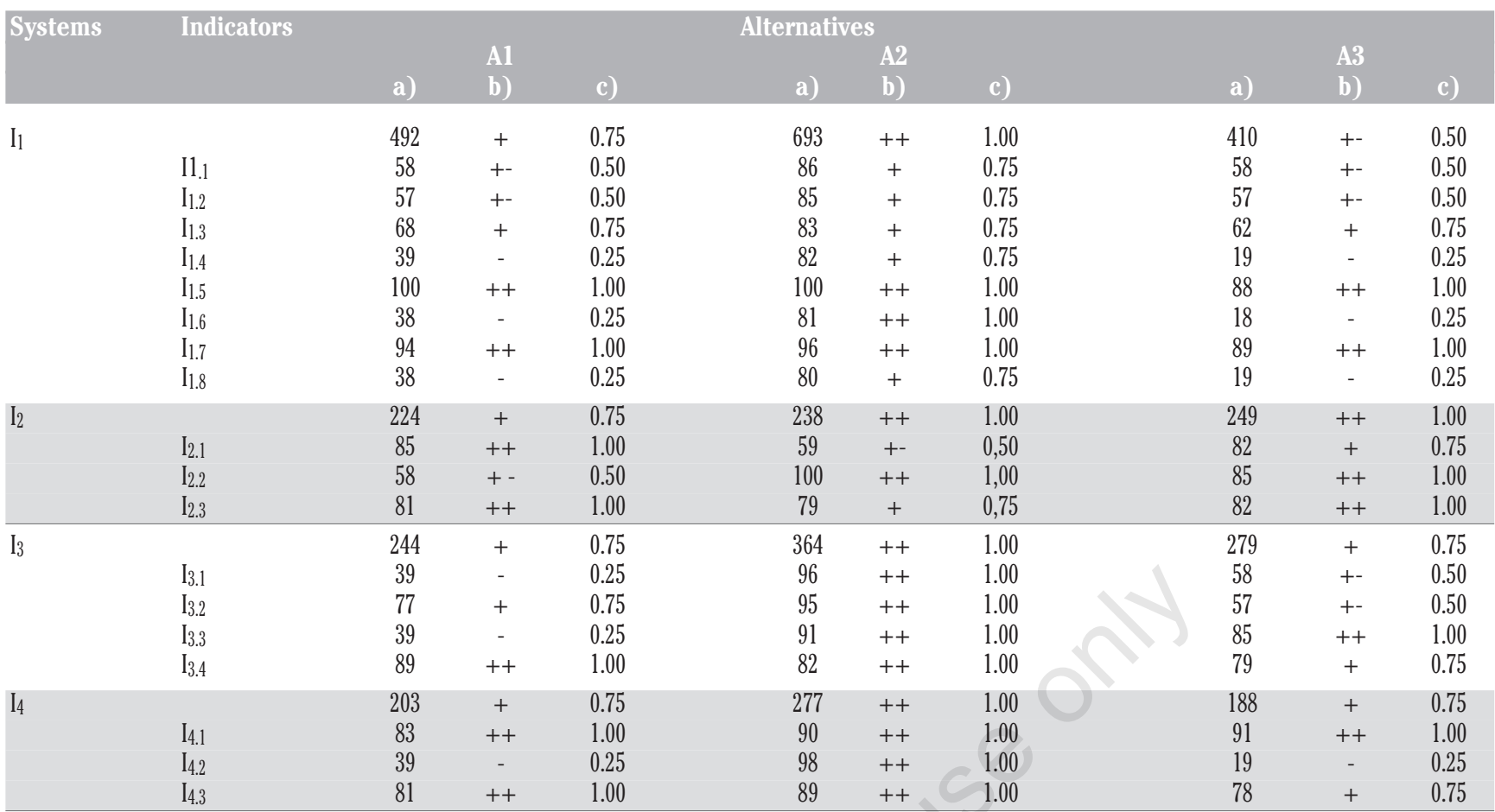

a) Number of preferences corresponding to the high value; b) symbol weight; c) normalised weight; $\mathrm{A}_{1}$, to establish a greenways network that can promote the development agro-rural; $\mathrm{A}_{2}$, to develop a greenways network can encourage the tourist, cultural use; $A_{3}$, to realise a network of greenways that can promote the use of environmental values; $I_{1}$, infrastructural system; $I_{2}$, agri-natural system; $I_{3}$, historical, cultural system; $I_{4}$, commercial system; I.1, highway; I1.2, national road; I1.3, regional and provincial road; I1.4, active railway lines; I.5, disused railway lines; I1.6, ports/airports; I.7, paths/royal country roads; I.8, parking/rest areas; I.1. land use; $I_{22}$, areas of significant landscape and environmental interest; $I_{23}$, waterways; $I_{3} I_{1}$, archaeological sites; $I_{32}$, Historical centres; $I_{3.3}$, museums and eco-museums; $I_{3.4}$, rural architecture/architectural landscape elements; $\mathrm{I}_{4.1}$, agricultural holdings/educational farms/agritourism; $\mathrm{I}_{4.2}$, hotel facilities/B\&B/hostels; $\mathrm{I}_{4.3}$, rural and folk festivals.

Table 6. Weights obtained by the pairwise comparison, weighed with those obtained from the interviews and priority values.

\begin{tabular}{|c|c|c|c|c|c|c|c|c|c|c|c|c|c|}
\hline In & $\mathrm{Inm}_{\mathrm{nm}}$ & P & $\begin{array}{l}\text { A1 } \\
\text { MV }\end{array}$ & $\begin{array}{c}\text { Priority In } \\
\text { (P*MV) }\end{array}$ & $\begin{array}{c}\text { Priority Inm } \\
\left(\mathrm{P}^{*} \mathrm{MV}\right)\end{array}$ & P & $\begin{array}{l}\text { A2 } \\
\text { MV }\end{array}$ & $\begin{array}{c}\text { Priority In } \\
\text { (P*MV) }\end{array}$ & $\begin{array}{l}\text { Priority Inm } \\
(\mathrm{P} * \mathrm{MV})\end{array}$ & $P$ & MV & $\begin{array}{c}\text { A3 } \\
\text { Priority In } \\
\text { (P*MV) }\end{array}$ & $\begin{array}{l}\text { Priority Inm } \\
\text { (P*MV) }\end{array}$ \\
\hline $\mathrm{I}_{1}$ & $\begin{array}{l}\mathrm{I}_{1.1} \\
\mathrm{I}_{1.2} \\
\mathrm{I}_{1.3} \\
\mathrm{I}_{1.4} \\
\mathrm{I}_{1.5} \\
\mathrm{I}_{1.6} \\
\mathrm{I}_{1.7} \\
\mathrm{I}_{1.8}\end{array}$ & $\begin{array}{l}0.20 \\
0.14 \\
0.09 \\
0.13 \\
0.13 \\
0.17 \\
0.12 \\
0.16 \\
0.05\end{array}$ & $\begin{array}{l}0.75 \\
0.50 \\
0.50 \\
0.75 \\
0.25 \\
1.00 \\
0.25 \\
1.00 \\
0.25\end{array}$ & 0.15 & $\begin{array}{l}0.07 \\
0.05 \\
0.10 \\
0.03 \\
0.17 \\
0.03 \\
0.16 \\
0.01\end{array}$ & $\begin{array}{l}0.21 \\
0.17 \\
0.08 \\
0.08 \\
0.16 \\
0.15 \\
0.17 \\
0.14 \\
0.05\end{array}$ & $\begin{array}{l}1.00 \\
0.75 \\
0.75 \\
0.75 \\
0.75 \\
1.00 \\
1.00 \\
1.00 \\
0.75\end{array}$ & 0.21 & $\begin{array}{l}0.13 \\
0.06 \\
0.06 \\
0.12 \\
0.15 \\
0.17 \\
0.14 \\
0.04\end{array}$ & $\begin{array}{l}0.13 \\
0.14 \\
0.07 \\
0.07 \\
0.15 \\
0.20 \\
0.13 \\
0.18 \\
0.05\end{array}$ & $\begin{array}{l}0.50 \\
0.50 \\
0.50 \\
0.75 \\
0.25 \\
1.00 \\
0.25 \\
1.00 \\
0.25\end{array}$ & 0.07 & $\begin{array}{l}0.07 \\
0.04 \\
0.05 \\
0.04 \\
0.20 \\
0.03 \\
0.18 \\
0.01\end{array}$ \\
\hline $\mathrm{I}_{2}$ & $\begin{array}{l}\mathrm{I}_{2.1} \\
\mathrm{I}_{2.2} \\
\mathrm{I}_{2.3}\end{array}$ & $\begin{array}{l}0.32 \\
0.66 \\
0.16 \\
0.19\end{array}$ & $\begin{array}{l}0.75 \\
1.00 \\
0.50 \\
1.00\end{array}$ & 0.24 & $\begin{array}{l}0.66 \\
0.08 \\
0.19\end{array}$ & $\begin{array}{l}0.30 \\
0.24 \\
0.55 \\
0.21\end{array}$ & $\begin{array}{l}1.00 \\
0.50 \\
1.00 \\
0.75\end{array}$ & 0.30 & $\begin{array}{l}0.12 \\
0.55 \\
0.16\end{array}$ & $\begin{array}{l}0.46 \\
0.26 \\
0.41 \\
0.33\end{array}$ & $\begin{array}{l}1.00 \\
0.75 \\
1.00 \\
1.00\end{array}$ & 0.46 & $\begin{array}{l}0.20 \\
0.41 \\
0.33 \\
\end{array}$ \\
\hline $\mathrm{I}_{3}$ & $\begin{array}{l}\mathrm{I}_{3.1} \\
\mathrm{I}_{3.2} \\
\mathrm{I}_{3.3} \\
\mathrm{I}_{3.4}\end{array}$ & $\begin{array}{l}0.19 \\
0.14 \\
0.23 \\
0.23 \\
0.39\end{array}$ & $\begin{array}{l}0.75 \\
0.25 \\
0.75 \\
0.25 \\
1.00\end{array}$ & 0.14 & $\begin{array}{l}0.25 \\
0.04 \\
0.17 \\
0.06 \\
0.39\end{array}$ & $\begin{array}{l}1.00 \\
0.31 \\
0.31 \\
0.24 \\
0.14\end{array}$ & $\begin{array}{l}1.00 \\
1.00 \\
1.00 \\
1.00\end{array}$ & 0.25 & $\begin{array}{l}0.31 \\
0.31 \\
0.24 \\
0.14\end{array}$ & $\begin{array}{l}0.17 \\
0.21 \\
0.21 \\
0.29 \\
0.29\end{array}$ & $\begin{array}{l}0.75 \\
0.50 \\
0.50 \\
1.00 \\
0.75\end{array}$ & 0.13 & $\begin{array}{l}0.11 \\
0.11 \\
0.29 \\
0.22\end{array}$ \\
\hline $\mathrm{I}_{4}$ & $\begin{array}{l}\mathrm{I}_{4.1} \\
\mathrm{I}_{4.2} \\
\mathrm{I} 4.3\end{array}$ & $\begin{array}{l}0.29 \\
0.50 \\
0.14 \\
0.37\end{array}$ & $\begin{array}{l}0.75 \\
1.00 \\
0.25 \\
1.00\end{array}$ & 0.22 & $\begin{array}{l}0.50 \\
0.04 \\
0.37\end{array}$ & $\begin{array}{l}0.24 \\
0.26 \\
0.41 \\
0.33\end{array}$ & $\begin{array}{l}1.00 \\
1.00 \\
1.00 \\
1.00\end{array}$ & 0.25 & $\begin{array}{l}0.25 \\
0.25 \\
0.25\end{array}$ & $\begin{array}{l}0.24 \\
0.43 \\
0.35 \\
0.22\end{array}$ & $\begin{array}{l}0.75 \\
1.00 \\
0.25 \\
0.75\end{array}$ & 0.18 & $\begin{array}{l}0.43 \\
0.09 \\
0.17\end{array}$ \\
\hline Tot In & & & & 0.75 & & & & 1.01 & & & & 0.83 & \\
\hline Tot $\mathrm{Inm}_{\mathrm{n}}$ & & & & & 3.11 & & & & 3.44 & & & & 2.96 \\
\hline
\end{tabular}

$\mathrm{I}_{\mathrm{n}}$, systems; $\mathrm{I}_{\mathrm{nm}}$, indicators; $\mathrm{P}$, weighs obtained by the pairwise comparison; MV, weights obtained by the weighted evaluation matrix; $\mathrm{A}_{1}$, to establish a greenways network that can promote the development agro-rural; $\mathrm{A}_{2}$, to develop a greenways network can encourage the tourist, cultural use; $\mathrm{A}_{3}$, to realise a network of greenways that can promote the use of environmental values; $I 1$, infrastructural system; $I_{2}$, agri-natural system;

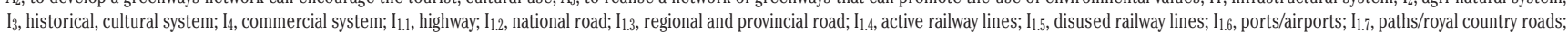
$\mathrm{I}_{1.8}$, parking/rest areas; $\mathrm{I}_{2.1}$, land use; $\mathrm{I}_{2.2}$, areas of significant landscape and environmental interest; $\mathrm{I}_{2.3}$, waterways; $I_{3.1}$, archaeological sites; $\mathrm{I}_{3.2}$, Historical centres; $\mathrm{I}_{3.3}$, museums and eco-museums; $\mathrm{I}_{3 .} 4$, rural architecture/architectural landscape elements; $\mathrm{I}_{4.1}$, agricultural holdings/educational farms/agritourism; $\mathrm{I}_{42}$, hotel facilities/B\&B/hostels; $\mathrm{I}_{4.3}$, rural and folk festivals. 
and railways $(100.00 \mathrm{~km})$, in addition to the national roads $(240.00$ kilometres), an extensive network of provincial roads (1243 km), country roads $(800.00 \mathrm{~km})$ and trails $(760.00$ kilometres) (Figure $3 \mathrm{~A})$. The airport is absent, at the moment this gap is filled by the presence of two nearby airports, located in other provinces (Catania and Ragusa). We have the presence of port facilities, especially for tourist purposes.

The indicators of the agro-natural system $\left(\mathrm{I}_{2}\right)$ show large extensive cultivated areas (about $461.15 \mathrm{~km}^{2}$ of arable land and $173.76 \mathrm{~km}^{2}$ of lawns and pastures) and intensive (about 362.77 $\mathrm{km}^{2}$ of agricultural woody crops). Numerous are the values associated with the presence of some exceptional historical and environ-
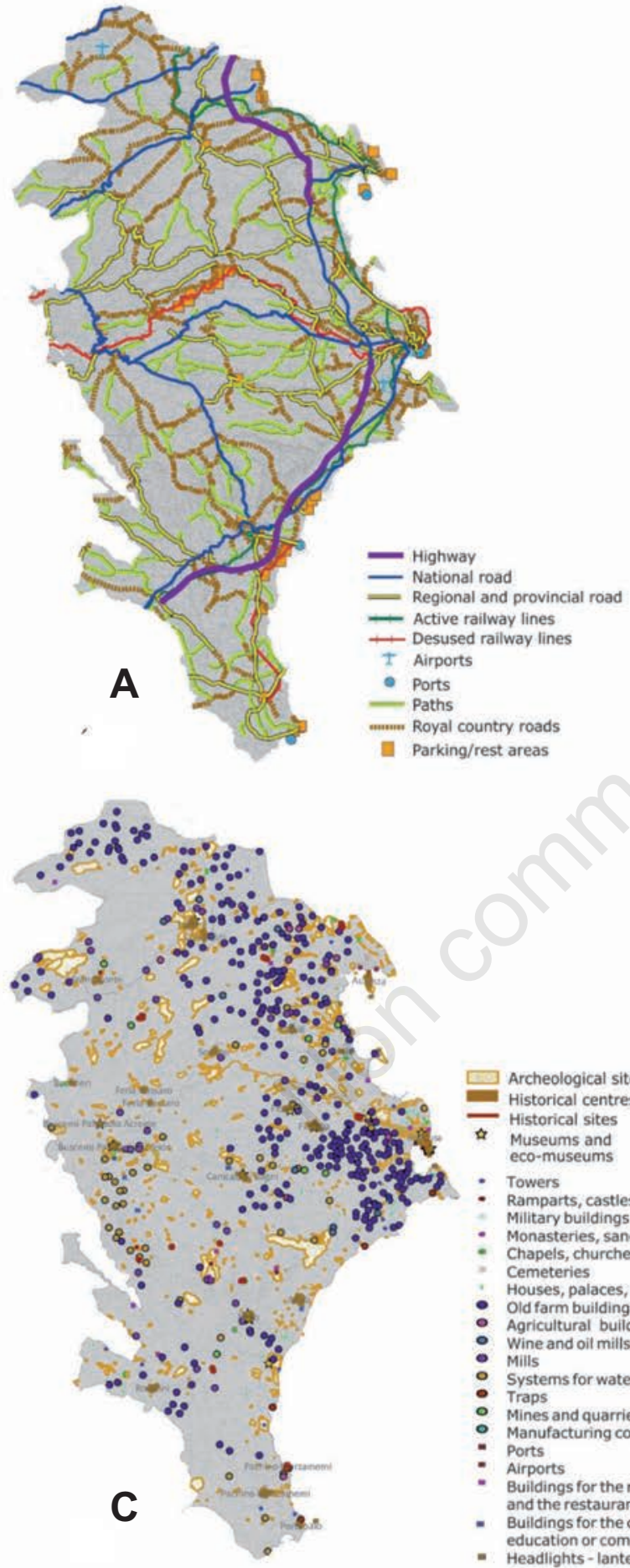

25
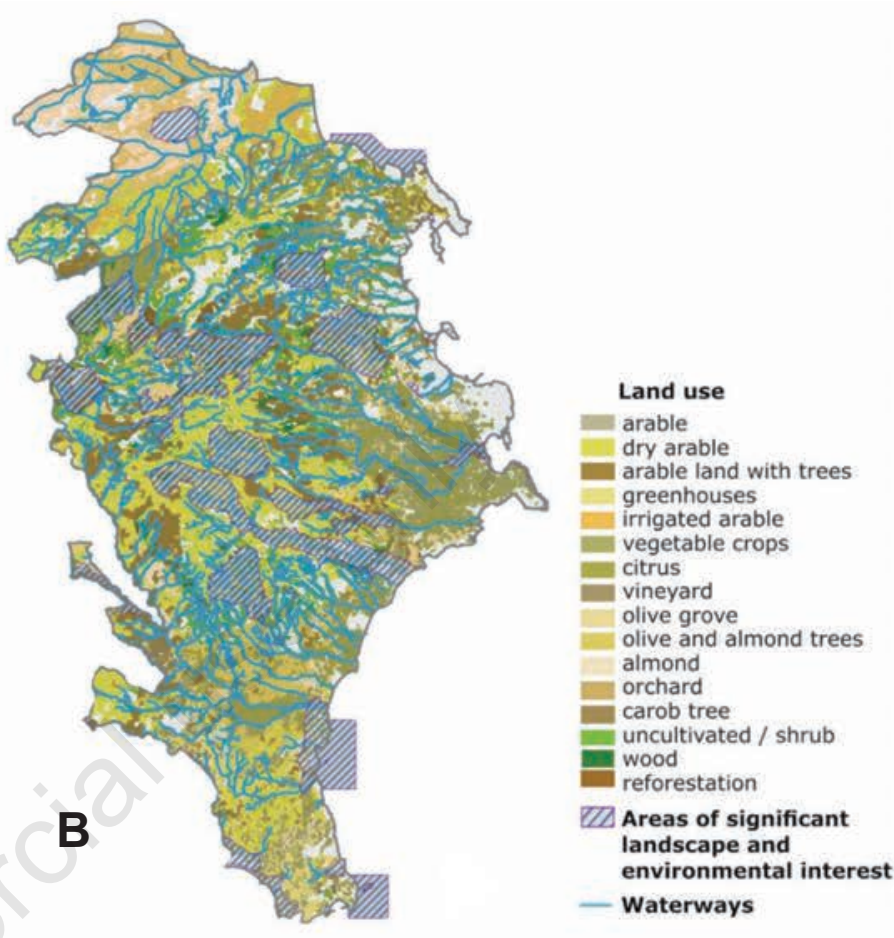

Agricultural holdings, agritourisms 1-2 (number)

3-5

4 6-9

1 10-19

Educational farms

$*$
$* 2$ Hostels

- $1-5$

- $6-10$

- $11-18$

- $41-56$

B \& B

\begin{tabular}{l} 
B \& \\
$-1-5$ \\
\hline
\end{tabular}

- 6-16

$17-30$
$91-131$

Rural and folk festivals

- $1-2$

* 3.5

Municipal limits

Figure 3. Indicators' maps: A) infrastructural system; B) agro-natural system; C) historical-cultural system; D) commercial system. 
mental value areas (Oriented Natural Regional Reserve Pantalica, Valley Stream and dell'Anapo Cavagrande, Natural Reserve Ciane and Saline of Syracuse, Natural Reserve Cavagrande of Syracuse, Nature Reserve Wildlife Oasis Vendicari Plemmirio Protected Area); there are 30 sites Nature 2000 and 297 streams of great
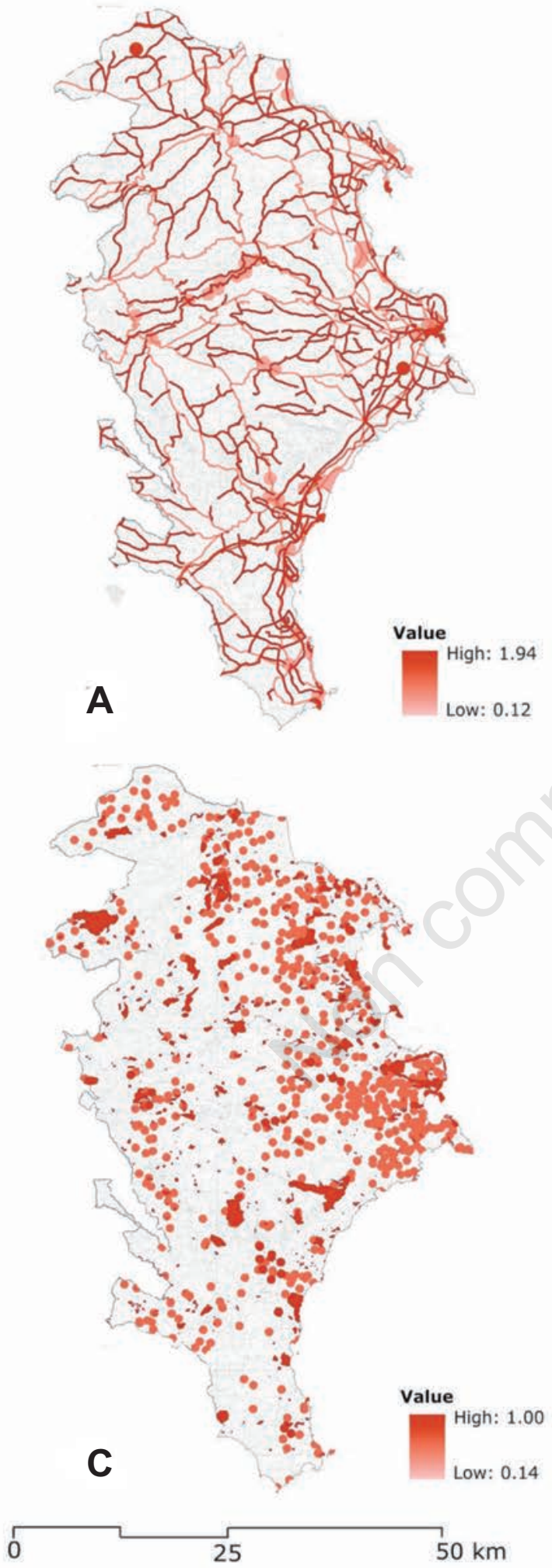

importance (the Anapo river which spreads 52.00 kilometres, the Ciane river is around $37.00 \mathrm{~km}$ long, the river Cassibile is around $50.00 \mathrm{~km}$ long, the river Tellaro is around $48.00 \mathrm{~km}$ ) long (Figure 3B).

The high historical, archaeological, architectural and land-
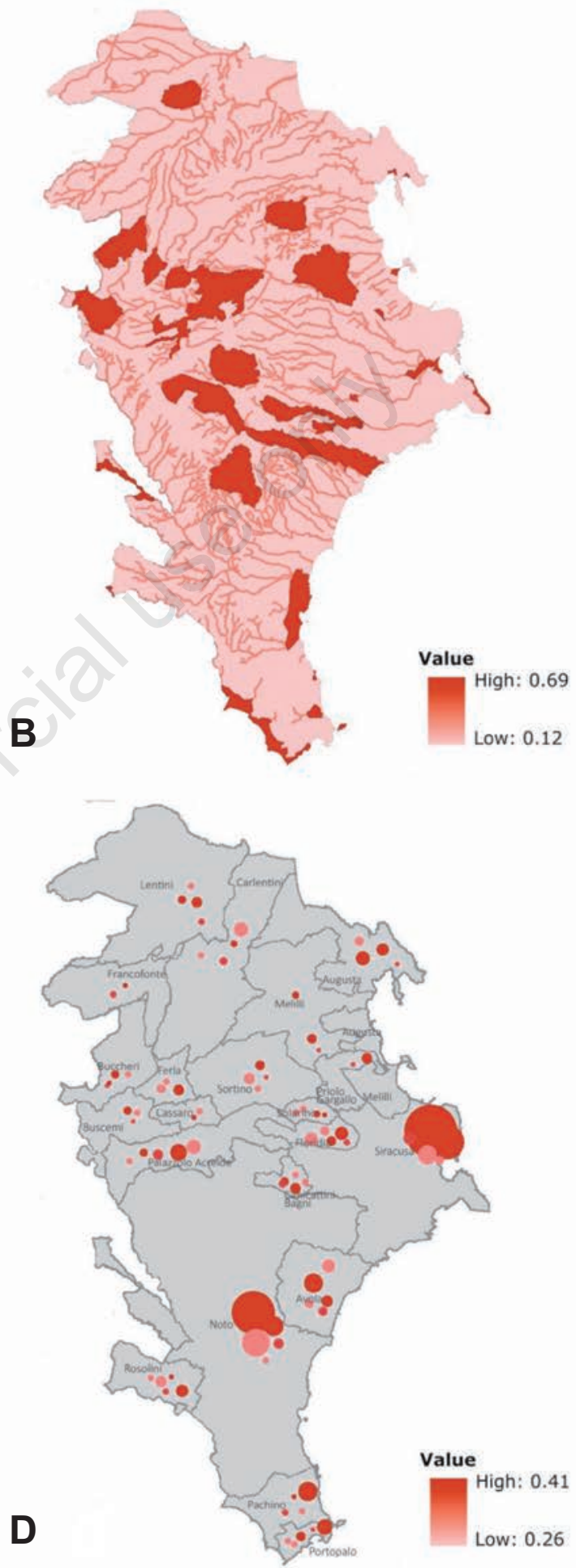

Figure 4. Weighted thematic maps: A) infrastructural system; B) agro-natural system; C) historical-cultural system; D) commercial system. 
scape profile of the territory emerges (historical-cultural system $\mathrm{I}_{3}$ ). We have to remember the following presences: 296 farms, 518 areas/archaeological sites (including the prehistoric settlement of Pantalica), the Baroque historic towns of Syracuse and Noto, the latter declared part of the UNESCO cultural heritage in 2005 (Figure 3C).

The indicators of the commercial system $\mathrm{I}_{4}$ show a good distribution of the activities related to trade and tourism. There are accommodation and commercial facilities (140 hotels, 308 B\&B, 62 agritourism, 17 educational farms) concentrated mainly in the coastal area and along the main infrastructures (Figure 3D).

The GIS value of the weights, obtained by associating the weight carriers and the qualitative evaluation, has produced the following results.

In the weighed map of the infrastructure system (Figure 4A), the value of the cells is very high in the elements that consider the disused railway lines (located in the central and in the south-east part of the territory) and the paths/royal country roads (distributed uniformly in all the whole territory), the highways (located in the north and south part of the provincial territory), and finally the ports (located mainly in the central/south area).

In the weighed map of the agro-natural system (Figure 4B), the value of the cells is very high in the central and southern swathe of the Syracuse territory, for the presence of natural reserves, parks and SAC/ASP areas with a 0.41 weight, prevails over all others.

In the weighed map of the cultural system (Figure 4C), we find the maximum values in the archaeological areas and in the areas that identify the historical centres. In addition, we report the presence of a large number of isolated assets disseminated in the territory.

In the weighed map of the commercial system (Figure 4D), we note how almost all the considered indicators have a high value. The accommodation facilities (hotels, B\&B and agritourism) and commercial resources, are distributed mainly in the central and southern swathe (especially in the towns of Syracuse and Noto; further south, in the coastal zone, near Porto Palo, Marzamemi and Pachino).

The sum of the weighed maps of the four systems (Figure 5) produces the map of alternative $\mathrm{A}_{2}$.

The maximum extended areas with the utmost values (dark red) are present in the central and southern part of the territory. The greatest importance is determined by the concomitant presence of most of the indicators, but primarily those with greater weight: nature reserves, parks and Natura 2000 sites, historical infrastructures, archaeological areas. Two of these areas are crossed by disused railways, while the many dark red islands are connected to each other by infrastructural tracks of intermediate tone, but anyhow important for the creation of the greenways network.

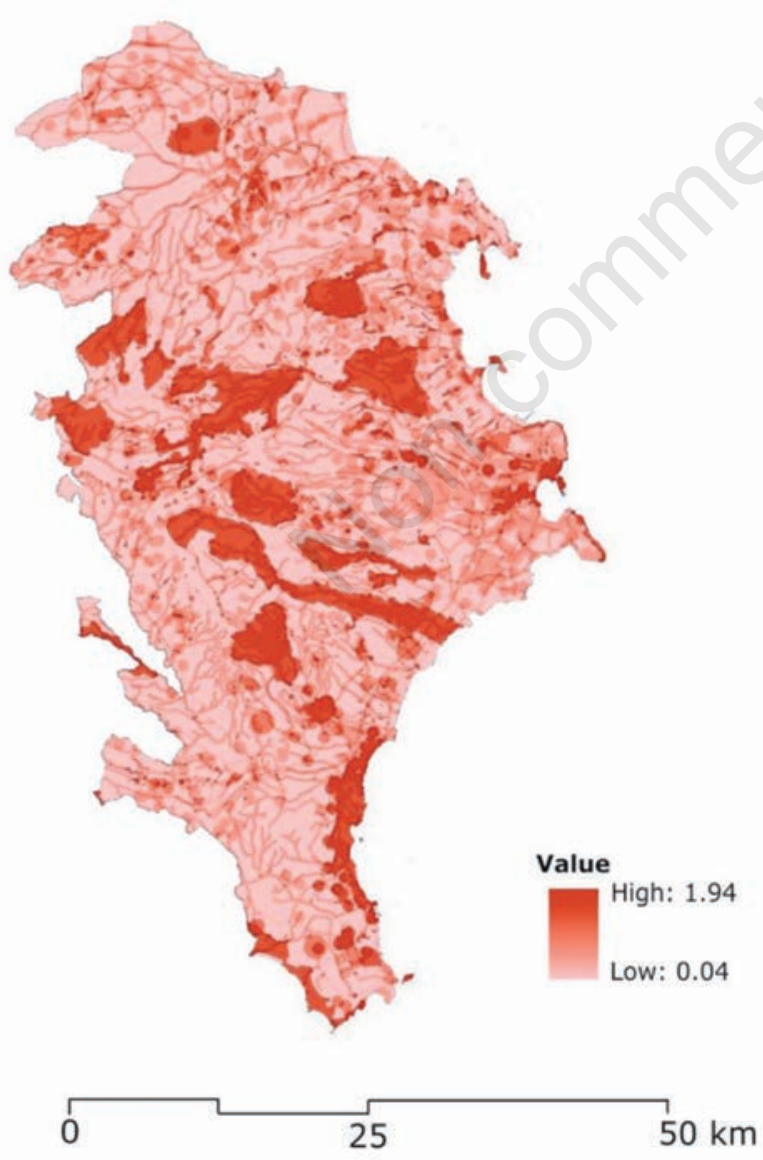

Figure 5. Sum of the weighted thematic maps in the alternative A2.

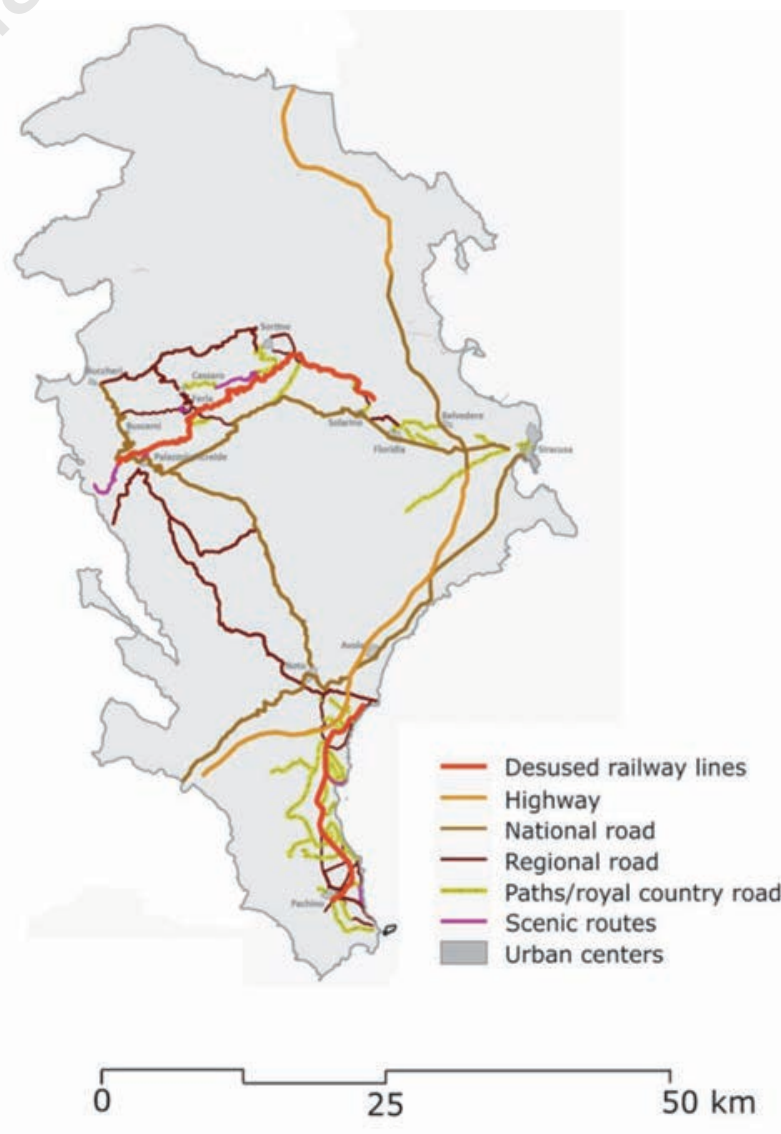

Figure 6. Main infrastructures that can fit a greenways network. 
The Figure 6 shows a hypothesis of infrastructural network suitable for this purpose. The network may consist of 55.50 kilometres of disused railways, 80.00 kilometres of royal country roads/rural paths, 22.00 kilometres of scenic routes, 184.00 kilometres of national roads, 135.00 kilometres of regional roads and it will also allow the rehabilitation of $\mathrm{n}$. 24 historic railway buildings (stations, signal boxes, warehouses) (Table 7). The disused railways are those mostly suitable not only for its own characteristics, but also because cross-important Natura 2000 sites and for the high attractiveness along the route. Therefore, it is particularly useable for tourist use (Taylor, 2015).

\section{Discussion and conclusions}

The research, initially, had been planned to locate the appropriate infrastructure network for the construction of greenways in the whole territory of Sicily region. The goal was to offer, the governing, territory and landscape management bodies, a bunch of knowledge to support the agro-touristic-cultural development policies, to integrate and complete the 2005 slow mobility plan. Subsequently, while keeping the initial objective, we have decided to direct our research to the study of a part of the regional territory, whose characteristics and potentialities could justify the commitment of financial resources to realise the greenways. The chosen PTPR landscape areas, n. 14 and n. 17, are among the most rich in natural and environmental resources, prehistoric and archaeological sites, well known around the world, in monumental and historical-artistic heritage, in towns of historical interest. The area also

Table 7. Dimensional characteristics of infrastructures for the establishment of a network of greenways.

\begin{tabular}{lcc}
\hline Infrastructures & Medium width (m) & Length (km) \\
Disused railway lines & 2.50 & 55.00 \\
Syracuse - Vizzini & 2.50 & 33.50 \\
\hline Noto - Pachino & 2.50 & 21.50 \\
National road & 6.45 & 184.00 \\
\hline SS124 Syracuse - Buccheri & 5.30 & 74.00 \\
SS287 Palazzolo Acreide - Noto & 6.00 & 28.00 \\
\hline SS115 Syracuse - Rosolini & 7.50 & 47.00 \\
SS114 Agnone - Syracuse & 7.00 & 35.00 \\
\hline Regional road & 5.95 & 135.00 \\
SP52 Floridia & 6.80 & 7.00 \\
\hline SP 29 Sortino - Buccheri & 5.30 & 15.00 \\
SP 24 Palazzolo - Noto & 5.00 & 30.00 \\
\hline SP 35 - SP 34 Noto - Calabernardo & 6.90 & 7.50 \\
SP 19 - Noto - Pachino - Marzamemi & 6.70 & 17.00 \\
\hline SP 84 - 97 Marzamemi - Pachino & 7.50 & 4.00 \\
SP 7 Buscemi - Cassaro & 4.50 & 11.00 \\
\hline SP 10 Cassaro - Ferla - SP 29 - Buccheri & 5.80 & 17.00 \\
SP 85 Pachino - Marzamemi & 5.00 & 4.50 \\
\hline SP 59 Lido di Noto & 6.00 & 11.00 \\
SP 80 Palazzolo Acreide & 5.90 & 11.00 \\
\hline Paths/royal country roads & 3.00 & 80.00 \\
Scenic routes & 3.00 & 22.00 \\
\hline & & \\
\hline
\end{tabular}

has a great variety of quality agricultural productions, of typical quality agro-food products, a strong local cultural identity illustrated by various and numerous popular presentations and a qualitatively adequate system of reception and services.

The used method, the MCA associated with the potential of GIS, is widely applied in the field of territory planning and several scientific papers illustrate its versatility (Fichera and Modica, 2007; Mirakyan and De Guio, 2013; Comino et al., 2014). This synergy has been proper for achieving the objective.

The direct survey has been a valuable support to the research, helping to make more objective the definition moment of the relative importance of the elements, included in the complex issue, avoiding that this phase were only attributed to the actors involved in this research.

The implementation of the multi-criteria phase, when takes into account residents' preferences, reduces the personal contribution in assigning the values in the pairwise comparison matrices. For assigning the values in the pairwise comparison, residents' preferences have been considered in a holistic way, considering the three levels (high, medium, low). The following weighting phase has allowed us to reduce further the personal contribution. The elaboration of respondents' choices only with high preference (to be read as the most positive expression to each alternative), has allowed strengthening weights' objectivity, resulting from the pairwise comparison.

We have not encountered any specific problem in applying the method, since it has already been adopted in other landscaping-territorial researches by the same authors (Riguccio et al., 2015b; Russo et al., 2013), whilst, the database accomplishment has been very laborious and has required the harmonisation with the multicriteria model and the geo-referencing of inconsistent data arriving from different sources. This last action has made the transfer of the weights obtained from the MCA and the subsequent acquisition of the weighted cartography easy in in a GIS environment.

We have identified the scenario that can make best use of the creation of a greenways network among the three considered scenarios $\left(A_{1}\right.$ - rural purposes, $A_{2}$ - tourist/cultural purposes, $A_{3}$ environmental objectives): the $\mathrm{A}_{2}$ scenario - tourist/cultural purposes has obtained a greater weight, both in the evaluation of the systems and in the evaluation the numerous indicators. The results agree with Taylor's statement (2015).

The Figure 5 map shows, in dark red tones, the areas of greatest interest for the construction of the network. Within these areas, all the considered infrastructures play a significant role in building the network, since they have been evaluated with regard to the presence of spatial and landscape resources. This does not mean that all infrastructures can be reconverted or adapted to greenways. The choice of the infrastructures for this purpose, must be addressed during the network planning phase, when the intrinsic characteristics of the roads, which indicate the adaptability or the conversion (width, slope, hazard, etc.) are considered in detail, but this part is not an objective of this study (Toccolini et al., 2006).

The tracks form the preferential axes of territory portions, where it is possible to start planning and management activities aimed at the improvement and use of the landscape, archaeological, historical and cultural property: it will be possible to manage and enhance the natural and man-made landscapes and the historical-architectural heritage in the territory, creating a fruition network composed of tourist-cultural itineraries.

This scenario, being mainly suitable for the tourist-cultural fruition, simultaneously offers many opportunities for the development of the agro-food and environmental components (Riguccio et al., 2017). 
Figure 6 shows a possible greenways network, presented considering the high concentration of resources. Certainly, not all the chosen infrastructures have intrinsic features suitable for slow paths, but all the infrastructures with appropriate signage or linked in computerised communication systems (mobile phone applications), in a network logic, can play an important role for the use and/or connection of the real greenways routes. For example, although a motorway, with no doubt, is not useable by pedestrians or cyclists, it is however important, to easily reach areas dedicated to non-motorised use, such as greenways on dismissed railroad tracks.

This study results could represent the basis to start extensive studies on specific sections of the network, in such a way to provide guidelines for the adjustment of the various infrastructure types, or detail projects.

Moreover, the study could be extended to the entire region if the territory government bodies show a real interest. The hope is that in future we can create greenways in the whole region, formed by a network of public slow mobility infrastructure, connected to each other and connecting natural spaces, places of historic and artistic interest, and facilitating a conscious and responsible approach by network users.

If we consider that the survey results of the population preferences, which has committed remarkable human resources, are of public utility, and that can be considered valid for the whole region - considering the cultural and social homogeneity - the necessary resources to extend the research to the regional territory are only those related to data collection, to their harmonisation and to the application of the method, therefore activities to be largely carried out in the laboratory. Data and calculations could converge and enrich WebGis of the Sicily region.

The obtained results may be viewed as a demonstration of the validity of this study, and we hope they will be of interest for the regional bodies.

\section{References}

Ahern J. 1995. Greenways as a planning strategy. Landscape Urban Plan. 33:131-55.

Bateman S. 2006. Making ecological networks and greenways a reality. Divers. Distrib. 12:220-7.

Caliandro L.P, Loisi R.V., Dal Sasso P. 2014. Connections between masserie and historical roads system in Apulia. J. Agric. Engine. 224:15-23.

Comino E., Bottero M., Pomarico S., Rosso M. 2014. Exploring the environmental value of eco system services for a river basin through a spatial multicriteria analysis. Land Use Policy 36:381-95

De Montis A., Caschili S., Ganciu A., Ledda A, Paoli F., Puddu F., Barra M. 2016. Strategic environmental assessment implementation of trasport and mobility plans. The case of Italian regions and provinces. J. Agricult. Engine. 47:100-10.

De Montis A., Ledda A, Ganciu A., Serra V., De Montis S. 2015. Recovery of rural centres and "albergo diffuso": A case study in Sardinia, Italy. Land Use Policy 47:12-28.

Diti I., Torreggiani D., Tassinari P. 2015. Rural landscape and cultural routes: a multicriteria spatial classification method tested on an Italian case study. J. Agricult. Engine. 46:23-29.

Fábos J.G., Ryan R.L. 2004. International greenway planning: an introduction. Landscape Urban Plan. 68:143-46.

Fichera C.R., Laudari L., Modica G. 2015. Application, validation and comparison in different geographical contexts of an integrated model for the design of ecological networks. J. Agricult. Engine. 426:52-61.

Fichera C.R., Modica G. 2007. Definizione e strutturazione di un modello multicriteriale in ambiente GIS per la pianificazione sostenibile del territorio rurale. In: C.R Fichera (Ed.), Multifunzionalità e sviluppo sostenibile del territorio rurale. Iriti editore, Reggio Calabria, Italy, pp. 25-53.

Ho W. 2008. Integrated analytic hierarchy process and its applications: a literature review. Eur. J. Operat. Res. 186:211-28.

Keeney R.L. 1992. Value-focused thinking: a path to creative decision making. Harvard University Press, Cambridge, MA, USA.

Little C. 1990. Greenways for America. John Hopkins University Press, Baltimore, MD, USA.

Marcheggiani E., Galli A., Gulinck H. 2011. The characterisation of "living" landscapes: The role of mixed descriptors and volunteering geographic information. Proc. International Conference on Computational Science and Its Applications, ICCSA 2011, Santander, Spain; 6782 LNCS, 1:369-80.

Mauchline A.L. 2012. Environmental evaluation of agri-environment schemes using participatory approaches - Experiences of testing the agri-environmental footprint index. Land Use Policy 29:317-28.

Mazzino F., Ghersi A. 2002. Per un'analisi del paesaggio. Metodo conoscitivo, analitico e valutativo per operazioni di progettazione e di gestione. Gangemi Editore, Roma, Italy, pp. 26-34.

Miller W., Collins M.G., Steiner F.R., Cook E. 1998. An approach for greenway suitability analysis. Landscape Urban Plan. 42:91-105.

Mirakyan A., De Guio R. 2013. Integrated energy planning in cities and territories: a review of methods and tools. Renew. Sustain. Energy Rev. 22:289-97.

Ottomano Palmisano G., Govindan K., Loisi R.V., Dal Sasso P., Roma R. 2016. Greenways for rural sustainable development: an integration between geographic information systems and group analytic hierarchy process. Land Use Policy 50:429-40.

Regione Sicilia. 2005. Piano della mobilità non motorizzata in Sicilia. Decreto assessoriale del 6 Giugno 2005. In: GURS n. 28, 1 luglio 2005. Available from: http://www.regione. sicilia.it/turismo/trasporti/prt/piano $\% 20$ mobilita $\% 20$ non $\% 20$ motorizzata\%20in\%20Sicilia.htm

Riguccio L., Carullo L., Russo P., Tomaselli G. 2016. A landscape project for the coexistence of agriculture and nature: a proposal for the coastal area of a Natura 2000 site in Sicily (Italy). J. Agricult. Engine. 47:62-71.

Riguccio L., Russo P., Scandurra G., Tomaselli G. 2015a. Cultural landscape: stone towers on Mount Etna. Landscape Res. 40:294-317.

Riguccio L., Tomaselli G., Carullo L., Verde D., Russo P. 2017. Identifying areas suitable for wine tourism through the use of multi-criteria and GIS: the method and its application in the countryside around Mount Etna (Sicily). J. Agricult. Engine. 48:88-98.

Riguccio L., Tomaselli G., Russo P., Falanga C. 2015b. Identification of "Typical Agricultural Districts" for the development of rural areas applied to Eastern Sicily. Land Use Policy 44:122-30.

Russo P., Riguccio L., Carullo L., Tomaselli G. 2013. Using the analytic hierarchical process to define choices for re-using rural buildings: application to an abandoned village in Sicily. Natural Resour. 4:323-32.

Russo P., Tomaselli G., Pappalardo G. 2014. Marginal periurban 
agricultural areas: a support method for landscape planning. Land Use Policy 41:97-109.

Saaty T.L. 1990. How to make a decision: the analytic hierarchy process. Eur. J. Operat. Res. 48:9-26.

Senes G. 2004. Il censimento delle line ferroviarie dismesse in Italia. In: Ferrovie, territorio e sistema di greenways. ISFORT, Roma, Italy, pp. 96-101.

Taylor P. 2015. What factors make rail trails successful as tourism attractions? Developing a conceptual framework from relevant literature. J. Outdoor Recreat. Tour. 12:89-98.

Toccolini A. 2004. La presentazione della ricerca condotta dall'Università di Milano sulle Greenways. In: Ferrovie, territorio e sistema di greenways. ISFORT, Roma, 92-95.

Toccolini A., Fumagalli N., Senes G. 2006. Greenways planning in Italy: the Lambro river valley greenways system. Landscape Urban Plan. 76:98-111. 